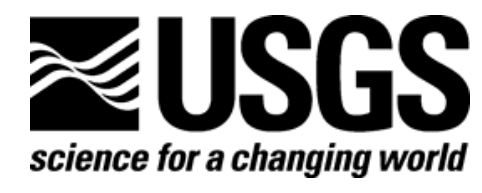

In cooperation with the National Park Service

\title{
Coastal Vulnerability Assessment of Cape Cod National Seashore (CACO) to Sea-Level Rise
}

By Erika S. Hammar-Klose, Elizabeth A. Pendleton, E. Robert Thieler, S. Jeffress Williams

Open File Report 02-233

U.S. Department of the Interior U.S. Geological Survey 


\section{U.S. Department of the Interior Gale A. Norton, Secretary}

\section{U.S. Geological Survey Charles G. Groat, Director}

\section{U.S. Geological Survey, Reston, Virginia}

For product and ordering information:

World Wide Web: http://www.usgs.gov/pubprod

Telephone: 1-888-ASK-USGS

For more information on the USGS - the Federal source for science about the Earth, its natural and living resources, natural hazards, and the environment:

World Wide Web: http://www.usgs.gov

Telephone: 1-888-ASK-USGS

For additional information about coastal vulnerability:

See the National Park Unit Coastal Vulnerability

study at http://woodshole.er.usgs.gov/project-pages/nps-cvi/,

the National Coastal Vulnerability study at http://woodshole.er.usgs.gov/project-

pages/cvi/,

or view the USGS online fact sheet for this project in PDF format at

http://pubs.usgs.gov/fs/fs095-02/.

To visit the Cape Cod National Seashore go to http://www.nps.gov/caco/.

Contacts for this report:

E. Robert Thieler, S. Jeffress Williams, and Elizabeth A. Pendleton

U.S. Geological Survey

384 Woods Hole Road

Woods Hole, MA 02543

E-mail: rthieler@usgs.gov, jwilliams@usgs.gov, ependleton@usgs.gov

Telephone: 508-457-2200 or 508-548-8700

Rebecca Beavers

National Park Service

Natural Resource Program Center

Geologic Resources Division

P.0. Box 25287

Denver, CO 80225-0287

E-mail:Rebecca_Beavers@nps.gov

Telephone: 303-987-6945 
Suggested citation:

Hammar-Klose E.S., Pendleton, E.A., Thieler, E.R, Williams, SJ., 2003, Coastal

Vulnerability Assessment of Cape Cod National Seashore (CACO) to Sea-Level Rise,

U.S. Geological Survey, Open file Report 02-233

http://pubs.usgs.gov/of/2002/of02-233/

Any use of trade, product, or firm names is for descriptive purposes only and does not imply endorsement by the U.S. Government.

Although this report is in the public domain, permission must be secured from the individual copyright owners to reproduce any copyrighted material contained within this report. 


\section{Contents}

Abstract

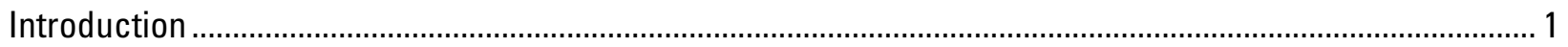

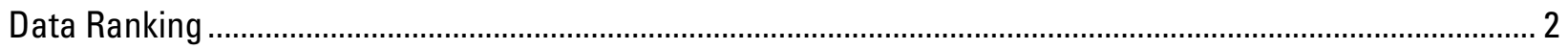

Coastal Geology of Cape Cod National Seashore …............................................................................ 3

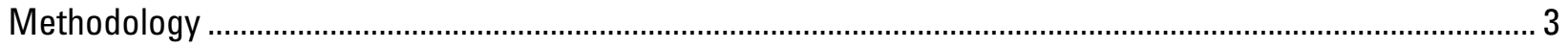

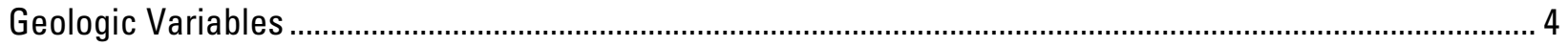

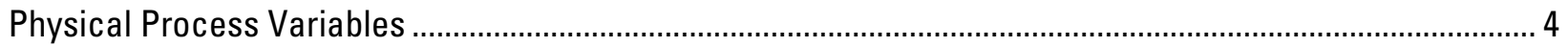

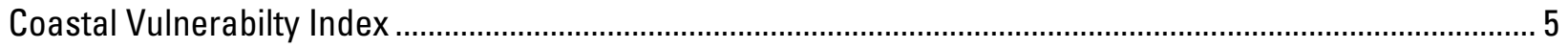

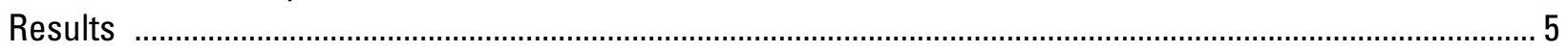

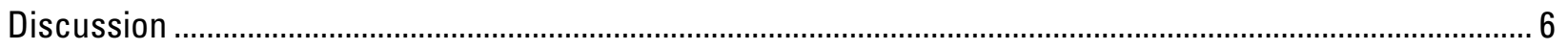

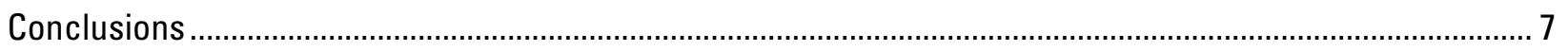

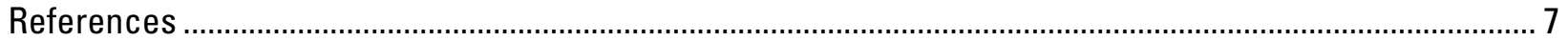

\section{Figures}

Figure 1. A) Location of Cape Cod National Seashore in southeastern New England, B) Cape

Cod National Seashore.

Figure 2. Shoreline grid for CACO

Figure 3. Race Point Beach is part of the Provincetown spit complex, but the extensive dunes and large sediment supply make this area a moderate geomorphologic vulnerability (panoramically distorted).

Figure 4. Cahoon Hollow has a high glacial cliff behind the beach-low vulnerability (panoramically distorted).

Figure 5. Great Island in Truro is a low barrier spit (very high vulnerability).. 12

Figure 6. Oblique view of glacial bluff at Cahoon Hollow Beach (low vulnerability) 12

Figure 7. View of Coast Guard Beach (very high vulnerability) from a glacial bluff (moderate vulnerability) Location on CACO where southern barrier spit transitions to glacial bluff.

Figure 8. Before and after photo of the breach of Nauset Spit, very high vulnerability barrier shoreline. The new inlet that formed was just less than $2 \mathrm{~km}$ wide at time of photograph (photos by Duncan FitzGerald)...

Figure 9. A) Historic shorelines for Nauset Spit in Chatham, this region has the highest standard deviation for shoreline change on CACO. B) Historic shorelines for Great Island in Truro, the spit is migrating landward and prograding to the south. C) Historic shorelines for Marconi Beach in Eastham, the glacial bluff in this area retreats at just less than $1 \mathrm{~m} / \mathrm{yr}$.

Figure 10. A) Regional coastal slope at Nauset Beach-high vulnerability. B) Regional coastal slope at Coast Guard Beach-moderate vulnerability. C) Regional coastal slope at Cahoon Hollow Beach-very low vulnerability. D) Regional coastal slope at Great Island--very high vulnerability. 
Figure 11. Relative Coastal Vulnerability for Cape Cod National Seashore. The innermost color bar is the relative coastal vulnerability index (CVI). The remaining color bars are separated into the geologic variables (1-3) and physical process variables (4-6). The very high vulnerability shoreline is along Nauset spit on the elbow of the Cape. High vulnerability shoreline is concentrated mostly within Cape Cod Bay. Moderate vulnerability shoreline is along the Provincetown spit complex, and the low vulnerability portion of the shore lies along the outer coast from Head of the Meadow Beach to Marconi Beach

Figure 12. Percentage of Cape Cod National Seashore in each vulnerability category.

\section{Tables}

Table 1. Ranges for Vulnerability Ranking of Variables on the Atlantic Coast. 


\title{
Coastal Vulnerability Assessment of Cape Cod National Seashore (CACO) to Sea-Level Rise
}

\author{
By Erika S. Hammar-Klose, Elizabeth A. Pendleton, E. Robert Thieler, S. Jeffress Williams
}

\section{U.S. Geological Survey Open-File Report 02-233}

\begin{abstract}
A coastal vulnerability index (CVI) was used to map the relative vulnerability of the coast to future sea-level rise within the Cape Cod National Seashore (CACO). The CVI ranks the following in terms of their physical contribution to sea-level rise-related coastal change: geomorphology, regional coastal slope, rate of relative sea-level rise, shoreline change rates, mean tidal range and mean wave height. The rankings for each variable were combined and an index value calculated for 1-minute grid cells covering the park. The CVI highlights those regions where the physical effects of sea-level rise might be the greatest. This approach combines the coastal system's susceptibility to change with its natural ability to adapt to changing environmental conditions, yielding a quantitative, although relative, measure of the park's natural vulnerability to the effects of sea-level rise. CACO consists of high glacial cliffs, beaches, sand spits, and salt marsh wetlands. The areas most vulnerable to sea-level rise are those with the lowest regional coastal slopes, geomorphologic types that are susceptible to inundation, and the highest rates of shoreline change. Most of CACO's infrastructure lies on high elevation uplands away from the shore; most high use areas are accessible by foot only. The CVI provides an objective technique for evaluation and long-term planning by scientists and park managers.
\end{abstract}

\section{Introduction}

The National Park Service (NPS) is responsible for maintaining nearly 12,000 km (7,500 miles) of shoreline along oceans and lakes. In 2001, the U.S. Geological Survey (USGS), in partnership with the NPS Geologic Resources Division, began conducting hazard assessments of future sealevel change by creating maps to assist NPS in managing its valuable coastal resources. This report presents the results of a vulnerability assessment for Cape Cod National Seashore (CACO), highlighting areas that are likely to be most affected by future sea-level rise.

Global sea-level has risen approximately 18 centimeters $(7.1$ inches) in the past century (Douglas, 1997). Climate models predict an additional rise of $48 \mathrm{~cm}$ (18.9 in.) by 2100 (IPCC, 2001), which is more than double the rate of rise for the 20th century. Potential coastal impacts of sea-level rise include shoreline erosion, saltwater intrusion to groundwater aquifers, inundation of wetlands and 
estuaries, and threats to cultural and historic resources as well as infrastructure. Predicted accelerated global sea-level rise has generated a need in coastal geology to determine the response of a coastline to sea-level rise. However, an accurate and quantitative approach to predicting coastal change is difficult to establish. Even the kinds of data necessary to make shoreline response predictions are the subject of scientific debate. A number of predictive approaches have been proposed (National Research Council, 1990), including: 1) extrapolation of historical data (e.g., coastal erosion rates), 2) static inundation modeling, 3) application of a simple geometric model (e.g., the Bruun Rule), 4) application of a sediment dynamics/budget model, or 5) Monte Carlo (probabilistic) simulation based on parameterized physical forcing variables. However, each of these approaches has inadequacies or can be invalid for certain applications (National Research Council, 1990). Additionally, shoreline response to sea-level change is further complicated by human modification of the natural coast such as beach nourishment projects, engineered structures like seawalls, groins, and jetties. Thus, understanding how a natural or modified coast will respond to sea-level change is essential to preserving vulnerable coastal resources.

The primary challenge in predicting shoreline response to sea-level rise is quantifying the important variables that contribute to coastal evolution in a given area. In order to address the multi-faceted task of predicting sea-level rise impact, the USGS has implemented a methodology to identify areas that may be most vulnerable to sea-level rise in the future (see Hammar-Klose and Thieler, 2001). This technique focuses on six variables which strongly influence coastal evolution:
1) Geomorphology
2) Shoreline change rate
3) Coastal slope
4) Relative sea-level change
5) Mean significant wave height
6) Mean tidal range

These variables can be divided into two groups: 1) geologic variables and 2) physical process variables. The geologic variables are geomorphology, historic shoreline change, and coastal slope; they account for a shoreline's relative resistance to erosion, long-term erosion/accretion trend, and its susceptibility to flooding, respectively. The physical process variables include significant wave height, tidal range, and sea-level, all of which contribute to the inundation hazards of a particular section of coastline over time scales from hours to centuries. A relatively simple vulnerability ranking system (Table 1$)$ allows the six variables to be incorporated into an equation that produces a coastal vulnerability index ( $\mathrm{CVI})$. The CVI can be used by scientists and park managers to evaluate the likelihood that physical change may occur along a shoreline as sealevel rises. Additionally, NPS staff will be able to incorporate information provided by this vulnerability assessment technique into General Management Plans.

\section{Data Ranking}

Table 1 shows the six physical variables described in the Introduction, which include both quantitative and qualitative information. Actual variable values are assigned a vulnerability ranking based on value ranges, whereas the non-numerical geomorphology variable is ranked qualitatively according to the relative resistance of a given landform to erosion. Shorelines with erosion/accretion rates between -1.0 and $+1.0 \mathrm{~m} / \mathrm{yr}$ are ranked as moderate. Increasingly higher 
erosion or accretion rates are ranked as correspondingly higher or lower vulnerability. Regional coastal slopes range from very high risk, $<0.3$ percent to very low risk at values $>1.2$ percent. The rate of relative sea-level change is ranked using the modern rate of eustatic rise $(1.8 \mathrm{~mm} / \mathrm{yr})$ as very low vulnerability. Since this is a global or "background" rate common to all shorelines, the sea-level rise ranking reflects primarily local to regional isostatic or tectonic adjustment. Mean wave height rankings range from very low $(<0.55 \mathrm{~m}) \mathrm{m}$ to very high $(>1.25 \mathrm{~m})$. Tidal range is ranked such that microtidal $(<1 \mathrm{~m})$ coasts are very high vulnerability and macrotidal $(>6 \mathrm{~m})$ coasts are very low vulnerability.

\section{Coastal Geology of Cape Cod National Seashore}

Cape Cod is the result of glacial deposition by the Laurentide ice sheet during the Late Wisconsinan. After the Laurentide ice sheet retreated from New England beginning around 18,000 years BP, Cape Cod emerged as a series of end moraines and outwash plains (Larson, 1982). Immediately following deglaciation, the shoreline of Cape Cod was an irregular hillock of unconsolidated sand and till covering bedrock to depths as great as $250 \mathrm{~m}$ (Oldale, 1992). Estimates of the maximum retreat of Cape Cod since waves began eroding its shoreline about 4000 BP have been approximately $4 \mathrm{~km}$ (Strahler, 1988). Consequently, Cape Cod National Seashore is extremely susceptible to natural weathering agents such as wind, waves, sea level fluctuations, storms, and tides (Figure 1). The shoreline of the outer cape is oriented such that the dominant east-northeast waves produce a bi-directional longshore transport system that transports outwash sediment eroded from cliffs to the north and south (Fisher, 1987). Sediment transported north is incorporated into the enlarging Provincetown spit system. Conversely, sediment transported to the south is supplied to the southern barrier spit system that extends from Coast Guard Beach to Monomoy Point. The portion of the seashore that extends from Ryder Beach to Great Island within Cape Cod Bay also experiences a net southerly longshore transport which has resulted in the growth of Great Island and the formation of Jeremy Point

\section{Methodology}

In order to develop a GIS database for a park-wide assessment of coastal vulnerability, data for each of the six variables described above were gathered from state and federal agencies (Table 2). The database is based on that used by Thieler and Hammar-Klose (1999) and loosely follows an earlier database developed by Gornitz and White (1992). A comparable assessment of the sensitivity of the Canadian coast to sea-level rise is presented by Shaw et al. (1998).

The database was constructed using a 1:70,000 Cape Cod shoreline that was produced from the medium resolution digital vector U.S. shoreline provided by the Strategic Environmental Assessments (SEA) Division of NOAA's Office of Ocean Resources Conservation and Assessment (ORCA) (http://seaserver.nos.noaa.gov/projects/shoreline/shoreline.html). Data for each of the six variables (geomorphology, shoreline change, coastal slope, relative sea-level rise, significant wave height, and tidal range) were joined to the shoreline using a 1 minute (approximately $1.5 \mathrm{~km}$ ) grid (Figure 2). The data were next assigned a relative vulnerability value from 1-5 ( 1 is very low vulnerability, 5 is very high vulnerability) based on the potential magnitude of its contribution to physical changes on the coast as sea level rises (Table 1). 


\section{Geologic Variables}

The geomorphology variable expresses the relative erodibility of different landform types (Table 1). These data were derived from 19941 meter resolution digital orthophotos (Table 2). In addition, field visits were made within the park to ground-truth the geomorphologic classification. The geomorphology of CACO varies from low vulnerability glacial cliffs to very high vulnerability barrier shoreline (Figures 3-8).

Shoreline erosion and accretion rates for $\mathrm{CACO}$ were calculated from existing shoreline data provided by USGS, Massachusetts Office of Coastal Zone Management, and Woods Hole Oceanographic Institution Seagrant (Thieler et al., 2001 and O'Connell et al., 2002). Shoreline rates of change were calculated at $20 \mathrm{~m}$ intervals (transects) along the coast using a linear regression technique to derive the rate of shoreline change over time (see Dolan,1985, for a general discussion of shoreline change calculation methods). The rates for each transect within a 1-minute grid cell were averaged to determine the shoreline change value used here. Shoreline change rates on CACO range from $+2 \mathrm{~m} / \mathrm{yr}$ (low vulnerability) to $-2 \mathrm{~m} / \mathrm{yr}$ (high vulnerability) (Figure 9 A-C).

The determination of regional coastal slope identifies the relative vulnerability of inundation and the potential rapidity of shoreline retreat because low-sloping coastal regions should retreat faster than steeper regions (Pilkey and Davis, 1987). The regional slope of the coastal zone was calculated from a grid of topographic and bathymetric elevations extending landward and seaward of the shoreline. Elevation data were obtained from the National Geophysical Data Center (NGDC) as gridded topographic and bathymetric elevations at 0.1 meter vertical resolution for 3 arc-second $(\sim 90 \mathrm{~m})$ grid cells. These data were resampled to 1-minute resolution (Figure 2). Regional coastal slopes for CACO vary from very low vulnerability to very high vulnerability (Figure $10 \mathrm{~A}-\mathrm{D})$.

\section{Physical Process Variables}

The relative sea-level change variable is derived from the increase or decrease in annual mean water elevation over time as measured at tide gauge stations along the coast. The rate of sealevel rise is $2.65+/-0.10 \mathrm{~mm} / \mathrm{yr}$ and $2.59+/-0.12 \mathrm{~mm} / \mathrm{yr}$ in Boston Harbor and Woods Hole, based on 79 and 68 years of data, respectively (Zervas, 2001). This variable inherently includes both eustatic (global) sea-level rise as well as regional sea-level rise due to isostatic and tectonic adjustments. Relative sea-level change data are a historical record, and thus only portray the recent sea level trend ( $<150$ years). Relative sea-level rise for CACO $(2.59-2.65 \mathrm{~mm} / \mathrm{yr})$ fall within moderate vulnerability.

Mean Significant Wave height is used here as a proxy for wave energy which drives the coastal sediment budget. Wave energy is directly related to the square of wave height;

$$
E=1 / 8 \rho g H^{2}
$$

where $E$ is energy density, $H$ is wave height, $\rho$ is water density and $g$ is acceleration due to gravity. Thus, the ability to mobilize and transport beach material is a function of wave height. In this report, we use hindcast nearshore mean significant wave height data for the period 1976-95 obtained from the U.S. Army Corps of Engineers Wave Information Study (WIS) 
(see references in Hubertz et al., 1996). The model wave heights were compared to historical measured wave height data obtained from the NOAA National Data Buoy Center to ensure that model values were representative of the study area. For CACO, mean significant wave heights range from very high to moderate risk.

Tide range is linked to both permanent and episodic inundation hazards. Tide range data were obtained from NOAA/NOS for three ocean tide stations along Cape Cod; the values were contoured along the park shoreline and mapped to the 1-minute grid cells. Most of CACO has a tidal range between 2 and 4 meters (moderate vulnerability), but a small portion of the outer Cape is between 1 and 2 meters (high vulnerability).

\section{Coastal Vulnerability Index}

The coastal vulnerability index (CVI) presented here is the same as that used in Thieler and Hammar-Klose (1999) and is similar to that used in Gornitz et al. (1994), as well as to the sensitivity index employed by Shaw et al. (1998). The CVI allows the six physical variables to be related in a quantifiable manner that expresses the relative vulnerability of the coast to physical changes due to future sea-level rise. This method yields numerical data that cannot be equated directly with particular physical effects. It does, however, highlight areas where the various effects of sea-level rise may be the greatest. Once each section of coastline is assigned a risk value for each specific data variable, the coastal vulnerability index (CVI) is calculated as the square root of the product of the ranked variables divided by the total number of variables;

$\mathrm{CVI}=\sqrt{\frac{\left(a^{*} b^{*} c^{*} d^{*} e^{*} f\right)}{6}}$

where, $\mathrm{a}=$ geomorphology, $\mathrm{b}=$ shoreline erosion/accretion rate, $\mathrm{c}=$ coastal slope, $\mathrm{d}=$ relative sea-level rise rate, $\mathrm{e}=$ mean wave height, and $\mathrm{f}=$ mean tide range.

The CVI values reported here apply specifically to Cape Cod National Seashore. Thus, absolute CVI values given for other coasts and parks are not directly comparable to the data presented here. To compare different coastal parks, the national-scale studies should be used (Thieler and Hammar-Klose, 1999, 2000a, 2000b). In addition to the CVI values, the data ranges are also subdivided using values different from other studies so that the values used here reflect only the relative vulnerability along this coast. We feel this approach best describes and highlights the vulnerability specific to each park.

\section{Results}

The calculated CVI values for CACO range from 6.71 to 31.62 The mean CVI value is 14.14; the mode is 6.71; and the median is 12.7. The standard deviation is 7.57. The 25th, 50th, and 75th percentiles are $7.3,12.0$, and 17.0, respectively.

Figure 11 shows a map of the coastal vulnerability index for the Cape Cod National Seashore. The CVI scores are divided into low, moderate, high, and very high vulnerability categories based on the quartile ranges and visual inspection of the data. CVI values below 7.3 are assigned to the low vulnerability category. Values from 7.31 to 12.0 are considered moderate 
vulnerability. High vulnerability values lie between 12.01 and 17.0. CVI values above 17.0 are classified as very high vulnerability. Figure 12 shows a histogram of the percentage of CACO shoreline in each vulnerability category. Approximately 55 miles $(88 \mathrm{~km})$ of shoreline is evaluated along the national seashore. Of this total, 24 percent of the mapped shoreline is classified as being at very high vulnerability due to future sea-level rise. Twenty-six percent is classified as high vulnerability, 26 percent as moderate vulnerability, and 24 percent as low vulnerability.

\section{Discussion}

The data within the coastal vulnerability index (CVI) show variability at several spatial scales. However, the physical process variables maintain the most consistency over the extent of the shoreline (Figure 11). The value of the relative sea level variable is constant for the entire study area. The significant wave height vulnerability is very high for the outer cape and then decreases to moderate risk within Cape Cod Bay where fetch length decreases. Tidal range rankings are mostly moderate with a small high vulnerability section north and south of Coast Guard Beach.

The geologic variables show the most variability and thus have the most influence on the CVI value (Figure 11). Geomorphology in the park includes low vulnerability medium glacial cliffs, very high vulnerability sandy barrier beaches, as well as moderate and high vulnerability landforms (Figures 3-8). Vulnerability due to shoreline change along the seashore varies from low to high (Figure 9 A-C). The outer Cape (north of Coast Guard Beach to Head of the Meadow Beach) is labeled here as moderate vulnerability which would suggest a stable shoreline position such that all erosion/accretion rates fall within $1 \mathrm{~m} / \mathrm{yr}$, however, this region has historically experienced erosion rates just under $1 \mathrm{~m} / \mathrm{yr}$. Thus, accretion is not a common process in this part of $\mathrm{CACO}$, even though the moderate shoreline change ranking might suggest this. Regional coastal slope varies from very low vulnerability adjacent to Wilkinson Basin to very high vulnerability within Cape Cod Bay ( Figure 10 A-D).

There are four separate regions of relative coastal vulnerability within CACO as determined by CVI analysis. The highest (very high vulnerability) vulnerability region is in the most southern portion of CACO starting around Coast Guard Beach. Geomorphology is the variable that controls the CVI here, but relatively high rates of shoreline change and low coastal slopes also make this area more vulnerable. Regions of high vulnerability are distributed within the park, but the most consistent area of high vulnerability exists within Cape Cod Bay. High vulnerability within the park is a result of spit morphology combined with low coastal slopes and moderate wave energy. Moderate vulnerability shoreline is concentrated around the Provincetown spit system, and the CVI here is mostly controlled by the coastal slope and geomorphology. The lowest vulnerability shoreline is on the outer cape from Head of the Meadow Beach south to Marconi Beach. Here vulnerability is equally controlled by glacial cliff morphology and steep coastal slopes.

The most influential variables in the CVI are geomorphology and regional coastal slope; therefore they may be considered the dominant factors controlling how CACO will evolve as sea level rises. In most cases geomorphology reflects coastal slope such that the highest vulnerability landforms often have the lowest coastal slopes. Shoreline change, significant wave height, and tidal range have mostly large-scale $(>20 \mathrm{~km})$ secondary effects on the spatial variability of the CVI value. 


\section{Conclusions}

The coastal vulnerability index (CVI) provides insight into the relative potential of coastal change due to future sea-level rise. The maps and data presented here can be viewed in at least two ways:

1) as an example of where physical changes are most likely to occur as sea-level rises; and

2) as a planning tool for the Cape Cod National Seashore.

As ranked in this study, geomorphology and regional coastal slope are the most important variables in determining the CVI for CACO. Wave height, shoreline change, and tide range contribute only minor spatial variability in the coastal vulnerability index. The rate of sea-level rise is a constant value for the entire park.

CACO preserves a dynamic natural environment, which must be understood in order to be managed properly. The CVI is one way that a park can assess objectively the natural factors that contribute to the evolution of the coastal zone, and thus how the park may evolve in the future.

\section{References}

Dolan, R., 1985. Coastal erosion information system for the United States shorelines: Advanced technology for monitoring and processing global environmental data. Remote Sensing Soc., Reading, United Kingdom, p. 155-160.

Douglas, B.C., 1997. Global sea rise; a redetermination. Surveys in Geophysics, 18: 279-292.

Fisher, J.J., 1987. Shoreline development of the Glacial Cape Cod Coastline. In: FitzGerald, D.M. and Rosen, P.S. (eds.) Glaciated Coasts, Academic Press, Inc., San Diego, p. 279-305.

Gornitz, V. and White, T.W. 1992. A coastal hazards database for the U.S. West Coast. ORNL/CDIAC-81, NDP-043C. Oak Ridge National Laboratory, Oak Ridge, Tennessee.

Gornitz, V.M., Daniels, R.C., White, T.W., and Birdwell, K.R., 1994. The development of a coastal risk assessment database: Vulnerability to sea-level rise in the U.S. southeast. Journal of Coastal Research, Special Issue No. 12, p. 327-338.

Hammar-Klose, E.S., and Thieler, E.R., 2001. Coastal Vulnerability to Sea-Level Rise: A Preliminary Database for the U.S. Atlantic, Pacific, and Gulf of Mexico Coasts. U.S. Geological Series, Digital Data Series, DDS-68, 1 CD.

Hubertz, J.M., Thompson, E.F., and Wang, H.V., 1996. Wave Information Studies of U.S. coastlines: Annotated bibliography on coastal and ocean data assimilation. WIS Report 36, U.S. Army Engineer Waterways Experiment Station, Vicksburg, 31 p.

IPCC, 2002. Climate Change 2001: The Scientific Basis; Contribution of Working Group I to the Third Assessment Report of the Intergovernmental Panel on Climate Change, IPCC: Geneva, Switzerland, 563 p. Online 
Klein, R., and Nicholls, R., 1999. Assessment of Coastal Vulnerability to Climate Change. Ambio, 28 (2):

182-187.

Larson, G.J., 1982. Nonsynchronous retreat of ice lobes from southeastern Massachusetts. In: Larson, G.J., and Stone, B.D. (eds.) Late Wisconisinan glaciation of New England. Kendall/Hunt Publishing Company, Dubuque, Iowa, p. 101-114.

National Research Council, 1990. Managing Coastal Erosion. Washington: National Academy Press, $163 \mathrm{p}$.

National Research Council, 1995. Beach Nourishment and Protection. Washington: National Academy Press, 334 p.

O'Connell, J.F., E.R. Thieler, and Schupp, C., 2002. New Shoreline Change Data and Analysis for the Massachusetts Shore with Emphasis on Cape Cod and the Islands: Mid-1800s to 1994. Environment Cape Cod, Vol. 5, No. 1, p. 1-14.

Oldale, R.N., 2001. Cape Cod, Martha's Vineyard and Nantucket: The Geologic Story Revised and Updated. Parnassus Imprints, East Orleans, Masssachusetts, 208 p.

Pilkey, O.H., and Davis, T.W., 1987. An analysis of coastal recession models: North Carolina coast. In: D. Nummedal, O.H. Pilkey and J.D. Howard (eds.), Sea-level Fluctuation and Coastal Evolution. SEPM (Society for Sedimentary Geology) Special Publications No. 41, Tulsa, Oklahoma, p. 59-68.

Shaw, J., Taylor, R.B., Forbes, D.L., Ruz, M.-H., and Solomon, S., 1998. Sensitivity of the Canadian Coast to Sea-Level Rise, Geological Survey of Canada Bulletin 505, 114 p.

Strahler, A.N., 1988. A Geologists view of Cape Cod. Parnassas Imprints, East Orleans, Massachusetts.

Thieler, E.R., and Hammar-Klose, E.S., 1999. National Assessment of Coastal Vulnerability to Sea-Level Rise: U.S. Atlantic Coast. U.S. Geological Survey, Open-File Report 99-593, 1 sheet. Online

Thieler, E.R., and Hammar-Klose, E.S., 2000. National Assessment of Coastal Vulnerability to Sea-Level Rise: U.S. Pacific Coast. U.S. Geological Survey, Open-File Report 00-178, 1 sheet. Online

Thieler, E.R., and Hammar-Klose, E.S., 2000. National Assessment of Coastal Vulnerability to Sea-Level Rise: U.S. Gulf of Mexico Coast. U.S. Geological Survey, Open-File Report 00-179, 1 sheet. Online

Thieler, E.R., O'Connell, J. F., and Schupp, C. A., 2001. The Massachusetts Shoreline Change Project: 1800s to 1994, U.S. Geological Survey Administrative Report, 39 p., 76 map sheets at 1:10,000.

Zervas, C., 2001. Sea Level Variations of the United States 1854-1999, NOAA Technical Report NOS CO-OPS 36, $201 \mathrm{p}$. 


\section{FIGURES}

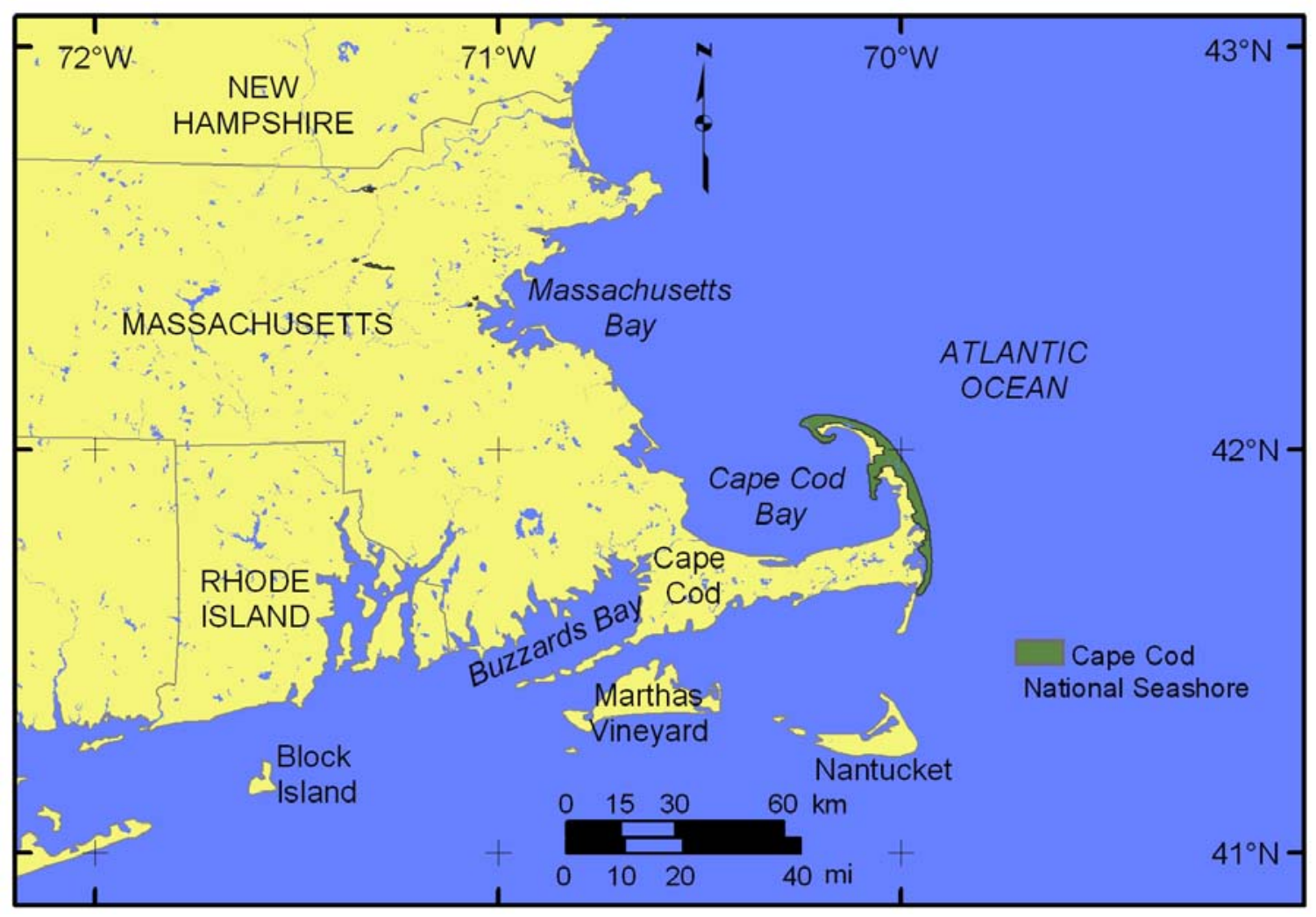

Figure 1. A) Location of Cape Cod National Seashore in southeastern New England. 


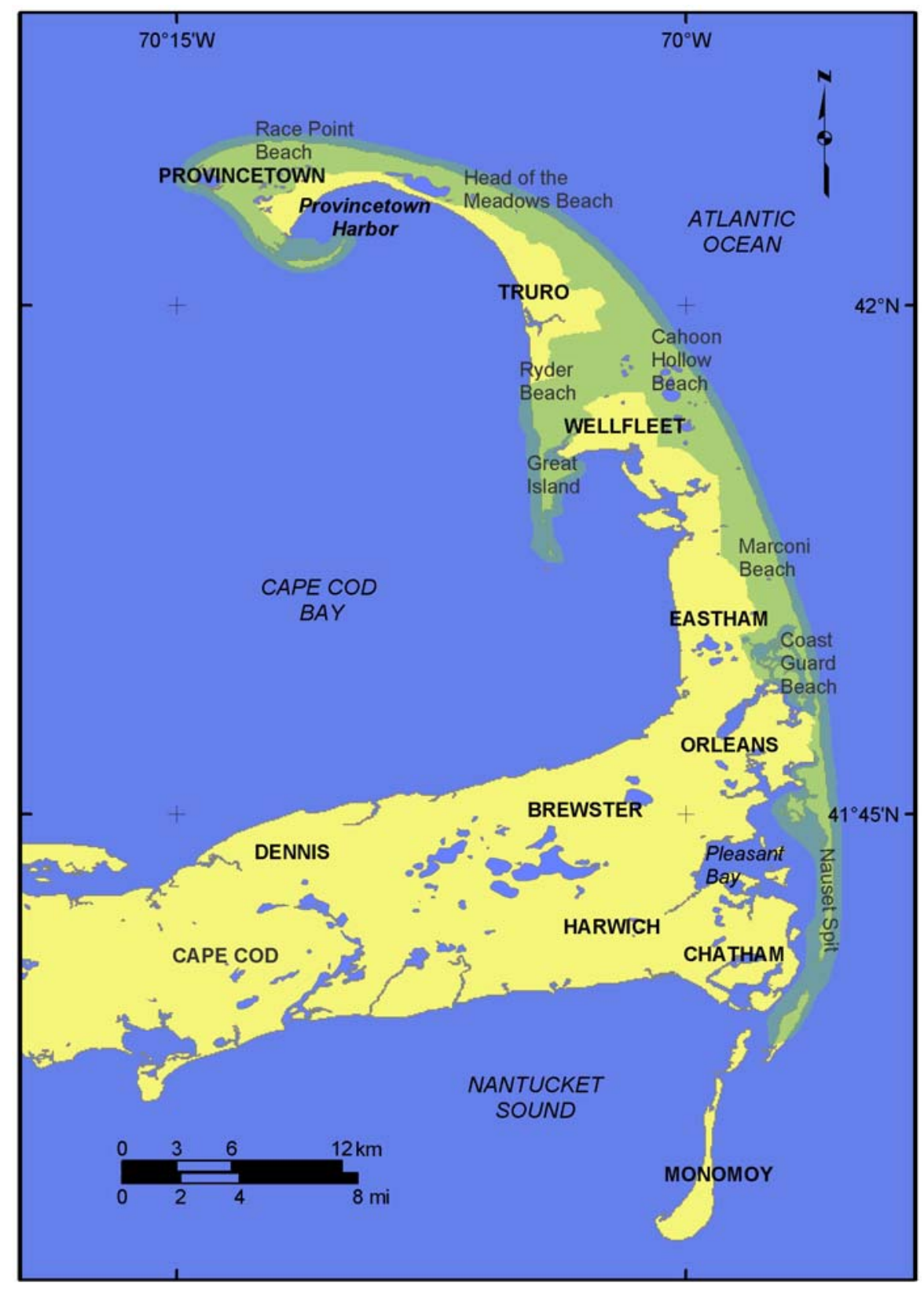

Figure 1. B) Cape Cod National Seashore. 


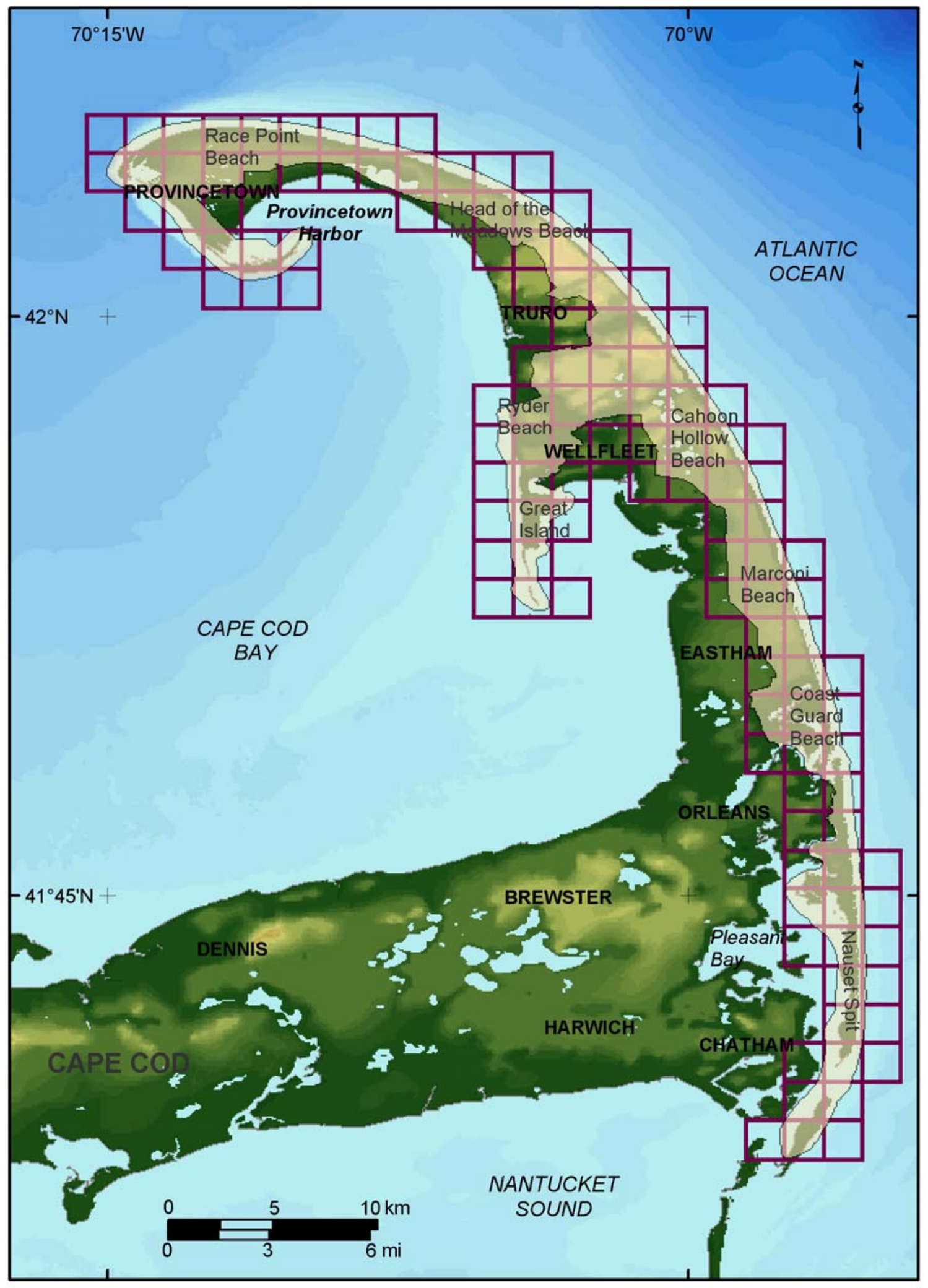

Figure 2. Shoreline grid for CACO. 


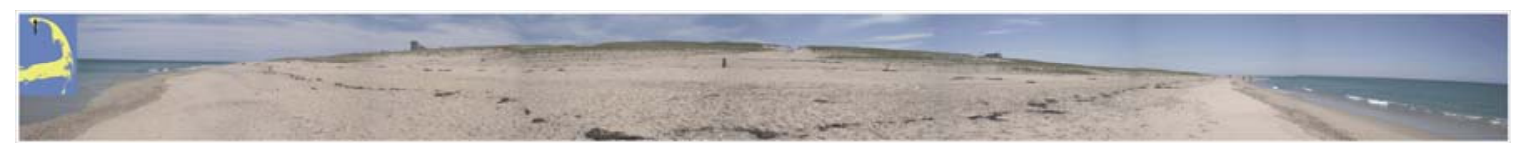

Figure 3. Race Point Beach is part of the Provincetown spit complex, but the extensive dunes and large sediment supply make this area a moderate geomorphologic vulnerability (panoramically distorted).

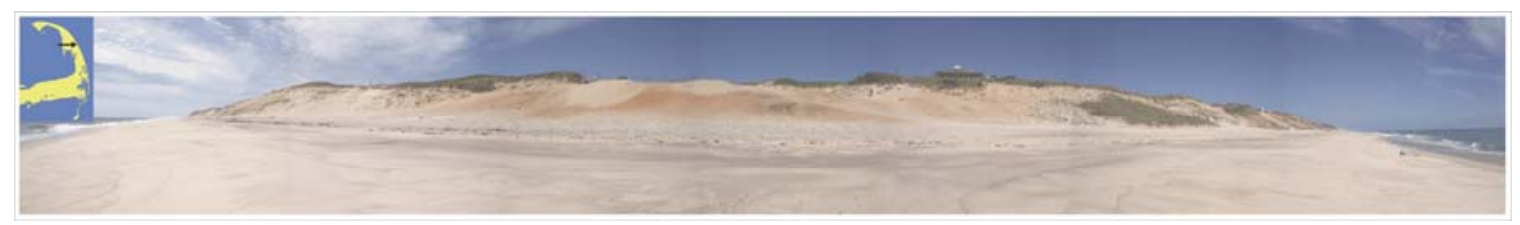

Figure 4. Cahoon Hollow has a high glacial cliff behind the beach-low vulnerability (panoramically distorted).

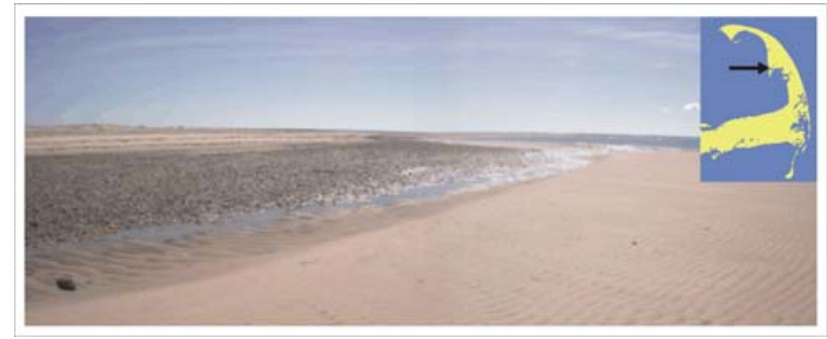

Figure 5. Great Island in Truro is a low barrier spit (very high vulnerability).

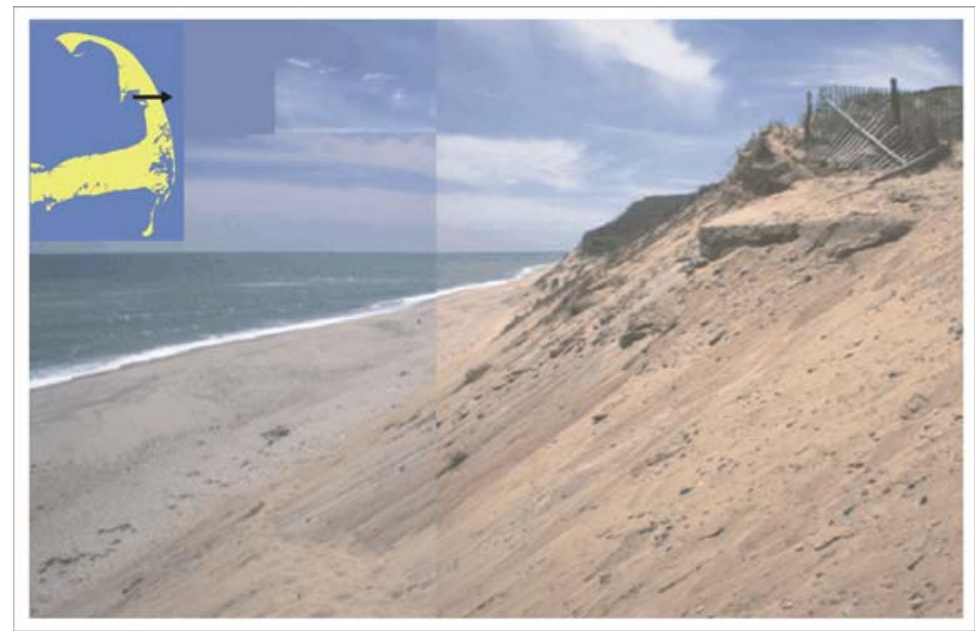

Figure 6. Oblique view of glacial bluff at Cahoon Hollow Beach (low vulnerability). 


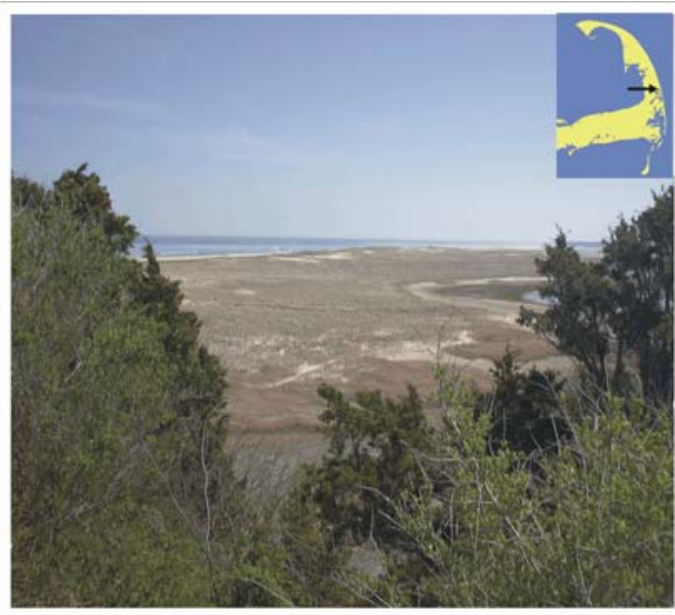

Figure 7. View of Coast Guard Beach (very high vulnerability) from a glacial bluff (moderate vulnerability).Location on CACO where southern barrier spit transitions to glacial bluff.

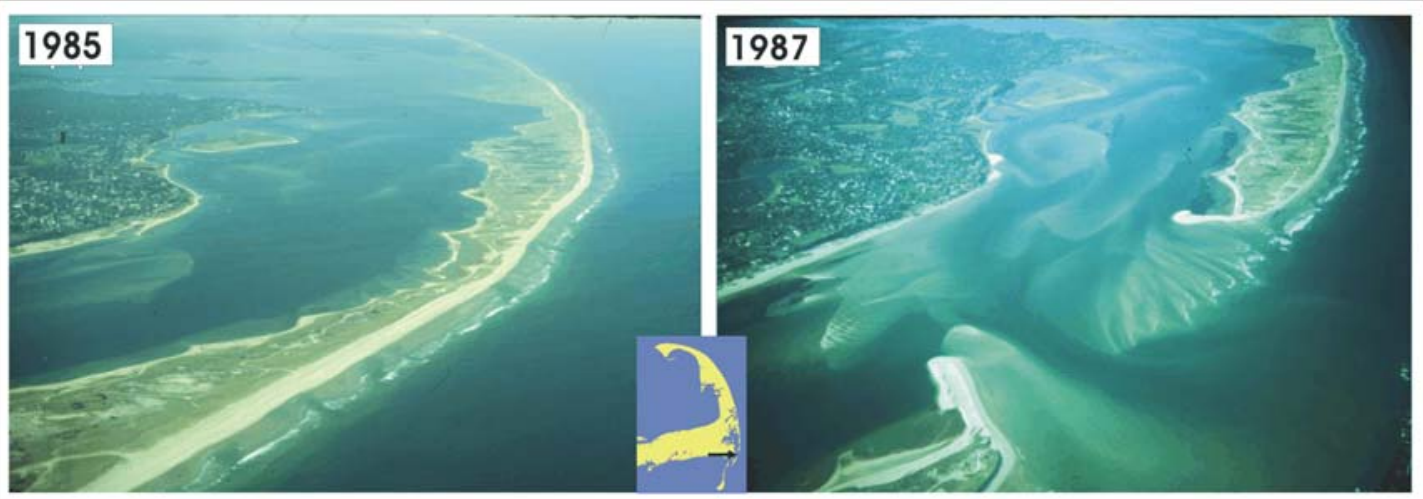

Figure 8. Before and after photo of the breach of Nauset Spit, very high vulnerability barrier shoreline. The new inlet that formed was just less than $2 \mathrm{~km}$ wide at time of photograph (photos by Duncan FitzGerald). 


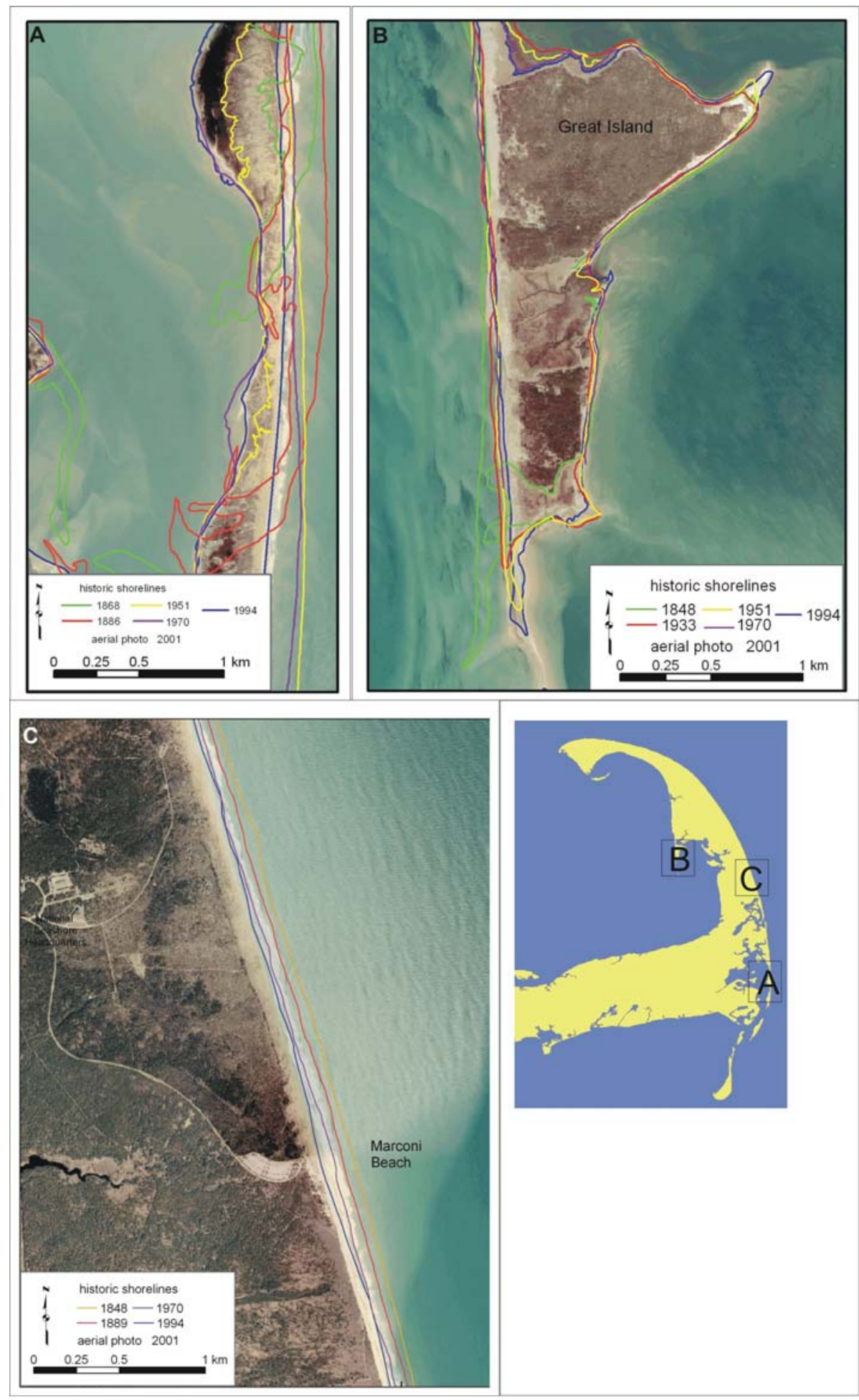

Figure 9. A) Historic shorelines for Nauset Spit in Chatham, this region has the highest standard deviation for shoreline change on CACO. B) Historic shorelines for Great Island in Truro, the spit is migrating landward and prograding to the south. C) Historic shorelines for Marconi Beach in Eastham, the glacial bluff in this area retreats at just less than $1 \mathrm{~m} / \mathrm{yr}$. 


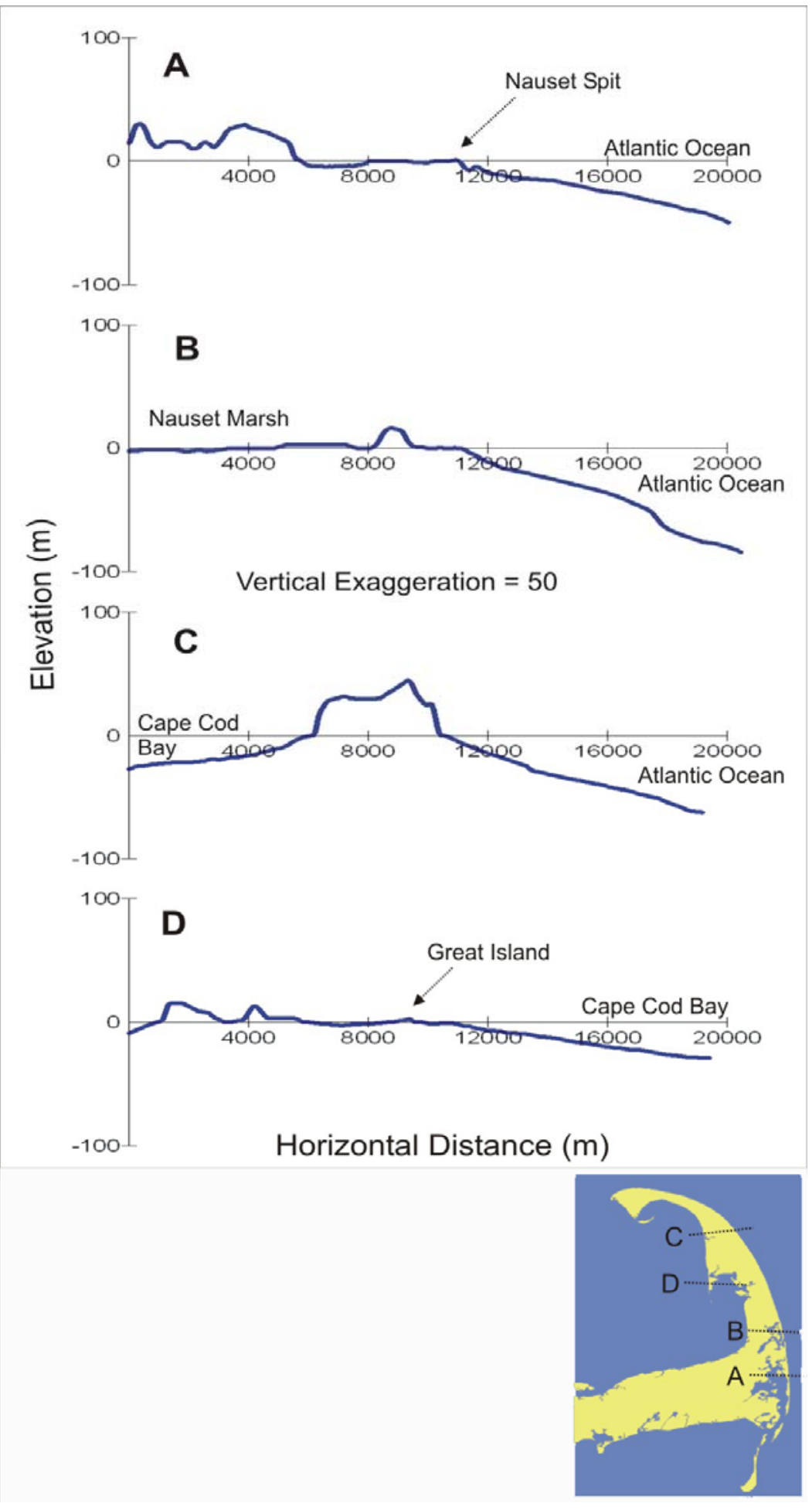

Figure 10. A) Regional coastal slope at Nauset Beach-high vulnerability. B) Regional coastal slope at Coast Guard Beach--moderate vulnerability. C) Regional coastal slope at Cahoon Hollow Beach-very low vulnerability. D) Regional coastal slope at Great Island-very high vulnerability. 


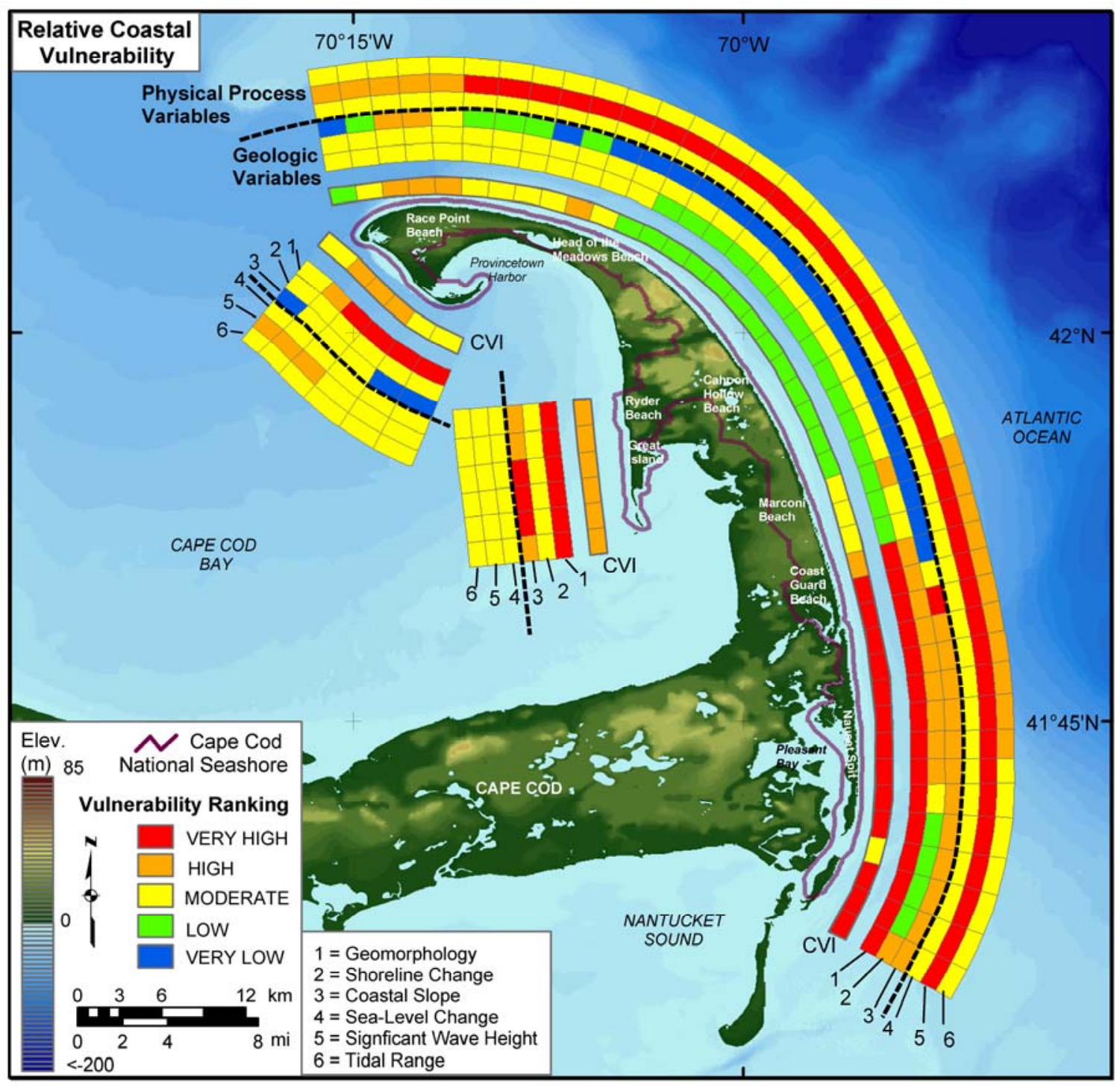

Figure 11. Relative Coastal Vulnerability for Cape Cod National Seashore. The innermost color bar is the relative coastal vulnerability index (CVI). The remaining color bars are separated into the geologic variables (1-3) and physical process variables (4-6). The very high vulnerability shoreline is along Nauset spit on the elbow of the Cape. High vulnerability shoreline is concentrated mostly within Cape Cod Bay. Moderate vulnerability shoreline is along the Provincetown spit complex, and the low vulnerability portion of the shore lies along the outer coast from Head of the Meadow Beach to Marconi Beach. 


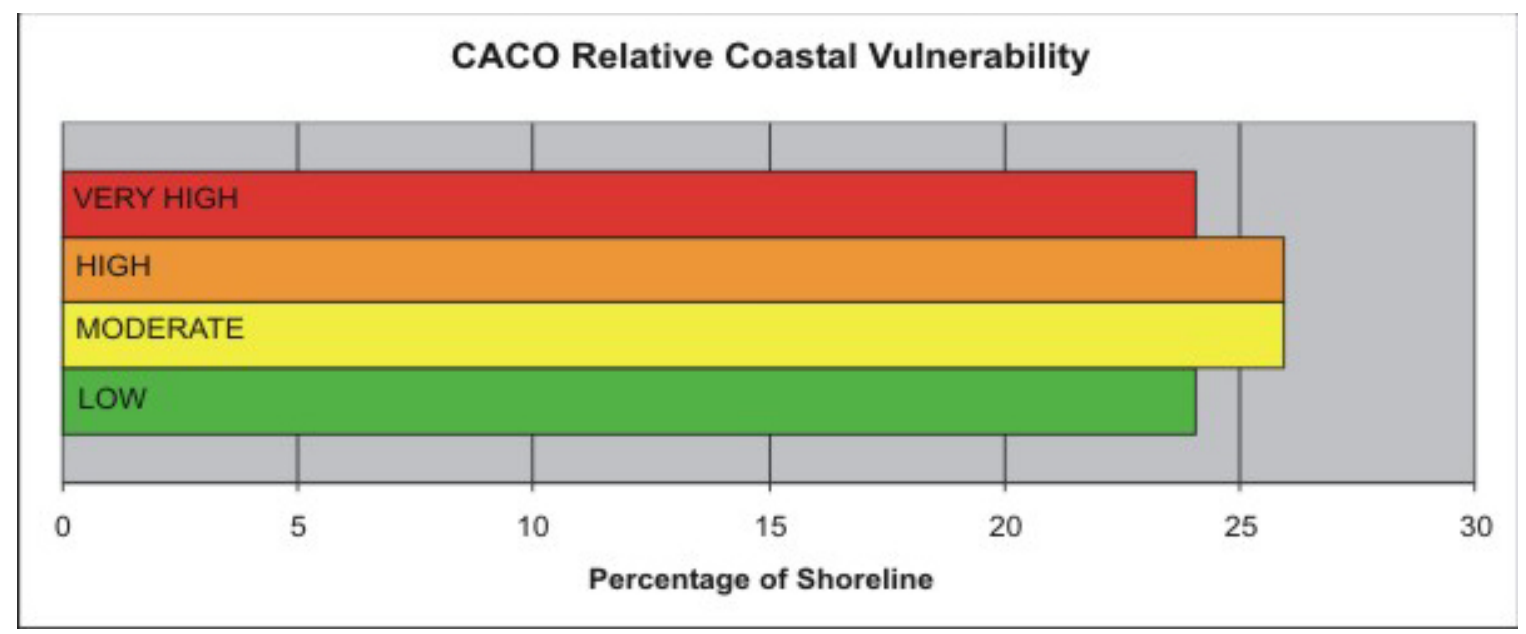

Figure 12. Percentage of Cape Cod National Seashore in each vulnerability category.

\section{TABLES}

Table 1: Ranges for Vulnerability Ranking of Variables on the Atlantic Coast.

\begin{tabular}{|c|c|c|c|c|c|}
\hline Variables & $\begin{array}{l}\text { Very Low } \\
1\end{array}$ & $\begin{array}{c}\text { Low } \\
2\end{array}$ & $\begin{array}{l}\text { Moderate } \\
\mathbf{3}\end{array}$ & $\begin{array}{c}\text { High } \\
4\end{array}$ & $\begin{array}{c}\text { Very High } \\
5\end{array}$ \\
\hline GEOMORPHOLOGY & $\begin{array}{l}\text { Rocky cliffed } \\
\text { coasts, Fjords }\end{array}$ & $\begin{array}{l}\text { Medium } \\
\text { cliffs, } \\
\text { Indented } \\
\text { coasts }\end{array}$ & $\begin{array}{l}\text { Low cliffs, } \\
\text { Glacial drift, } \\
\text { Alluvial } \\
\text { plains }\end{array}$ & $\begin{array}{l}\text { Cobble } \\
\text { Beaches, } \\
\text { Estuary, } \\
\text { Lagoon }\end{array}$ & $\begin{array}{l}\text { Barrier beaches, } \\
\text { Sand beaches, Salt } \\
\text { marsh, Mud flats, } \\
\text { Deltas, Mangrove, } \\
\text { Coral reefs }\end{array}$ \\
\hline $\begin{array}{c}\text { SHORELINE } \\
\text { EROSION/ACCRETION } \\
(\mathrm{m} / \mathrm{yr})\end{array}$ & $>2.0$ & $1.0-2.0$ & $-1.0-1.0$ & $-2.0--1.0$ & $<-2.0$ \\
\hline COASTAL SLOPE (\%) & $>1.20$ & $1.20-0.90$ & $0.90-0.60$ & $0.60-0.30$ & $<0.30$ \\
\hline $\begin{array}{l}\text { RELATIVE SEA- } \\
\text { LEVEL CHANGE } \\
\quad(\mathrm{mm} / \mathrm{yr})\end{array}$ & $<1.8$ & $1.8-2.5$ & $2.5-3.0$ & $3.0-3.4$ & $>3.4$ \\
\hline $\begin{array}{l}\text { MEAN WAVE HEIGHT } \\
(\mathrm{m})\end{array}$ & $<0.55$ & $0.55-0.85$ & $0.85-1.05$ & $1.05-1.25$ & $>1.25$ \\
\hline $\begin{array}{l}\text { MEAN TIDE RANGE } \\
(\mathrm{m})\end{array}$ & $>6.0$ & $4.0-6.0$ & $2.0-4.0$ & $1.0-2.0$ & $<1.0$ \\
\hline
\end{tabular}




\begin{tabular}{|c|c|c|}
\hline Variables & Source & URL \\
\hline GEOMORPHOLOGY & $\begin{array}{c}\text { Aerial } \\
\text { Photography } \\
\text { from MassGIS }\end{array}$ & http://www.state.ma.us/mgis/ \\
\hline $\begin{array}{c}\text { SHORELINE } \\
\text { EROSION/ACCRETION } \\
(\mathrm{m} / \mathrm{yr})\end{array}$ & $\begin{array}{l}\text { USGS } \\
\text { Administrative } \\
\text { Report: The } \\
\text { Massachusetts } \\
\text { Shoreline } \\
\text { Change Project: } \\
1800 \text { 's -1994 } \\
\text { (Thieler et al., } \\
\text { 2001) }\end{array}$ & http://www.state.ma.us/czm/shorelinechange.htm \\
\hline COASTAL SLOPE (\%) & \begin{tabular}{|c|} 
NGDC Coastal \\
Relief Model \\
Vol 01 \\
$12 / 17 / 1998$
\end{tabular} & http://www.ngdc.noaa.gov/mgg/coastal/coastal.html \\
\hline $\begin{array}{l}\text { RELATIVE SEA-LEVEL } \\
\text { CHANGE (mm/yr) }\end{array}$ & \begin{tabular}{|c} 
NOAA \\
Technical \\
Report NOS \\
CO-OPS 36 \\
SEA LEVEL \\
VARIATIONS \\
OF THE \\
UNITED \\
STATES 1854- \\
1999 (Zervas, \\
2001 )
\end{tabular} & $\begin{array}{l}\text { http://www.co- } \\
\text { ops.nos.noaa.gov/publications/techrpt36doc.pdf }\end{array}$ \\
\hline $\begin{array}{l}\text { MEAN WAVE HEIGHT } \\
(\mathrm{m})\end{array}$ & $\begin{array}{l}\text { North Atlantic } \\
\text { Region WIS } \\
\text { Data (Phase II) } \\
\text { and NOAA } \\
\text { National Data } \\
\text { Buoy Center }\end{array}$ & $\begin{array}{l}\text { http://bigfoot.wes.army.mil// } \\
\text { http://seaboard.ndbc.noaa.gov/ }\end{array}$ \\
\hline MEAN TIDE RANGE (m) & $\begin{array}{l}\text { NOAA/NOS } \\
\text { CO-OPS } \\
\text { Historical } \\
\text { Water Level } \\
\text { Station Index }\end{array}$ & http://www.co-ops.nos.noaa.gov/usmap.html \\
\hline
\end{tabular}

